\title{
Dutch particles in the right periphery
}

\author{
Ton van der Wouden, Meertens Instituut, ton.van.der.wouden@meertens.knaw.nl \\ Ad Foolen, Radboud Universiteit Nijmegen, a.foolen@let.ru.nl
}

\begin{abstract}
"Verglichen mit dem linken Rand hat der rechte Satzrand bislang wenig Aufmerksamkeit in der Linguistik erhalten." (Averintseva-Klisch 2009:1) [Compared to the left periphery, the right periphery has, up till now, received little attention in Linguistics]
\end{abstract}

\begin{abstract}
Although there is a considerable tradition of research into Dutch particles, particle behavior in the right periphery has not been part of it. This paper is a first exploratory expedition into this terra incognita. After a brief introduction into the syntax of the right periphery of the Dutch clause, we present a number of results of our search for sentence final particles in a large corpus of spoken Dutch. We argue that within the right periphery, various particle positions should be distinguished. A comparison is made with sentence final particles in other languages, and we compare Dutch sentence final particles with particles in other positions. We briefly address the phenomenon of particle doubling, in which two instances of the same particle occupy two positions in the clause, one being (somewhere) in the right periphery. We finally offer some speculations and conjectures with respect to grammaticalization of particles, and a tentative overview of the pragmatic functions sentence final particles can fulfill.
\end{abstract}

\section{Introduction}

This exploratory paper deals with sentence final particles in Dutch. By particles, we mean pragmatic particles: those elements that don't contribute to the propositional content of the sentence (cf. Foolen 1993). As is well known from pragmatic research, such particles are more typical for spoken than for written language. It would, thus, be better to say 'utterance final' than 'sentence final'.

The syntagmatic placement of pragmatic particles is variable, within languages (for Dutch, see section 6) and cross-linguistically. English discourse markers typically occur at the beginning of an utterance, German and Dutch modal particles are positioned in the middle field, in classical Greek the particles where attracted by the second position, whereas East Asian languages typically have their pragmatic particles at the end of the utterance. In section 5 we address the question whether there is any typological logic in such language specific preferences. We will argue that it is too early for typological conclusions, as not enough language specific descriptive work has been done.

This lack of descriptive research became more and more clear for us while working on the present project: Dutch is not known for its utterance final particles, not even among Dutch linguists, but while searching for the phenomenon in the Spoken Dutch Corpus (CGN), we discovered that in fact there is a wide variety of pragmatic particles to be found at the end of Dutch utterances, as we will show in section 4, where we will illustrate our findings with many examples from this corpus.

Given the title of this paper, we should briefly dwell upon the question what do we mean with the term 'right periphery'? At least since Koster (1975), Dutch is considered to be an SOV language. In subordinate clauses, the verbal elements, i.e. the finite verb and/or participles and infinitives, cluster at the end of the clause. In main clauses, this is also the case, albeit with the exception of the finite verb which moves to a position at the beginning of the clause (in generative terms: the C-position, "Verb second"). The SOV character of Dutch does not mean, however, that the verb cluster always constitutes an absolute end of the utterance, as has been shown by a wealth of studies, especially within generative 
frameworks. Processes such as "extraposition" and "right dislocation" have been proposed to account for constructions in which constituents are found after the verb cluster. We will use the term 'right periphery' for the structural positions and the words and phrases that follow the final verbal cluster.

The assumption of processes like extraposition and right dislocation suggests two structural positions in the right periphery. Such an assumption is indeed viable in both traditional and structural Dutch linguistics. However, where exactly utterance final pragmatic particles should be placed in relation to these two positions has hardly been a topic of discussion in the existing literature. We will go into this question in section 2 (on a more descriptive level) and in section 3 (on a more theoretical level).

In short, the outline of this paper is as follows. In section 2 and 3, we will explore the syntax of the right periphery, in section 4 we present an inventory of the particles we found in the right periphery. Section 5 till 9 contain some specific topics: a short comparison with other languages in section 5, an excursion into other syntactic positions in Dutch where pragmatic particles can be found, in particular the left periphery and middle field. In section 7 we pay attention to the phenomenon of doubling: one and the same particle occurring in the right periphery and in one of the other positions. Section 8 contains a few remarks on grammaticalization and section 9 contains a first inventory of functions that final particles can fulfill. Section 10 offers some concluding remarks on Dutch utterance-final particles.

\section{The right periphery in Dutch linguistics}

As indicated in section 1, Dutch linguistics traditionally distinguishes two structural positions in the right periphery (see, for example, the reference grammar of Dutch ANS (Haeseryn et al. 1997:1228-29)). The position directly to the right of the verbal end cluster is called 'laatste zinsplaats', lit. 'last sentence position'. This position can be identified with the result what is known as 'extraposition' from the generative literature (cf. e.g. Veld 1993). Often, this position is left empty, but if it is filled, then PPs and extraposed embedded clauses are typical occupants, cf. (1)

(1) a. Ik ben naar Amsterdam gereisd met de trein.

I am to Amsterdam travelled with the train

'I travelled to Amsterdam by train'

b. Ik heb van Peter gehoord dat je morgen dertig wordt.

I have from Peter heard that you tomorrow thirty become

'I heard from Peter that you turn thirty tomorrow'

The second structural position in the right periphery, following the extraposition position, is called 'uitloop', lit. 'outflow'. According to the ANS, it is separated from the 'sentence proper' by a comma intonation. Among other things, the position can be filled by a noun phrase which has already been referred to earlier in the sentence by a pronoun, cf. (2):

(2) Stonden die er al lang, die bomen?

Stood they there already long, those trees?

'Have they been there for a long time already, those trees?'

In the context of the present paper the relevant question is, of course, where utterance final pragmatic particles are placed in relation to these two structural positions. The most conservative hypothesis would be that they can fill one of the two or both these positions. However, examples can be constructed in which a pragmatic particle occurs before the two positions, in between them or after them, cf. (3):

(3) a. Hij zou zich steeds weer verzetten hoor [tegen een dergelijk voorstel]. He would himself always again oppose PRT against a such proposal 
'He would never cease to oppose that kind of proposals, don't forget that'

b. Hij zou zich steeds weer verzetten [tegen een dergelijk voorstel] hoor, [die kerel].

He would himself always again oppose against a such proposal PRT that guy 'That guy would never cease to oppose that kind of proposals, don't forget that'

c. Hij zou zich niet verzetten [tegen een dergelijk voorstel], [die kerel], integendeel.

He would himself not oppose against a such proposal, that guy, PRT

'That guy would never oppose such a proposal, on the contrary'

Specific particles show a preference for one of the three positions. For example, hoor would sound bad after an utterance which has both the extraposition and right dislocation position filled, whereas integendeel can only be placed at the end. In section 4, we will go through a longer list of pragmatic particles and pay attention to preferences like the ones mentioned here for hoor and integendeel.

At an observational level, we can thus distinguish at least three different syntactic positions for pragmatic particles in the right periphery. In the next section, we will discuss some theoretical frameworks which have tried to model pragmatic particles in the periphery (left and right).

\section{Towards a constructional analysis}

Cinque (1999) was the starting point for the so-called cartographic approach in generative syntactic theorizing. It opened the possibility to assume functional projections that had to do with discourse structure, such as TopP for 'topic' and FocP for 'focus', cf. Breul (2004), Benincà \& Munaro (eds.) (2010). In the line of this approach, proposals have been made to accommodate discourse particles in the left or right periphery in functional projections, cf. Poletto (2009) for Old Italian, Li (2006), Sybesma \& Li (2007) and Sybesma (2010) for Chinese, and Haegeman \& Hill (2010) for Rumanian and West Flemish (a Dutch dialect in the west of Belgium).

Haegeman \& Hill (2010) observe that wè and zè express a speaker attitude, whereas zé (with rising intonation) and né are hearer oriented. Based on this difference in discourse function, Haegeman \& Hill assume two functional projections, which allow a sequence of two particles, in the order speaker oriented - hearer oriented, for example wè zé or zè zé. Hierarchically, the latter projection dominates the former. As the authors point out themselves, their proposal is in the spirit of Ross (1970), who was one of the first to propose to expand the syntactic structure of the sentence to accommodate aspects of the speech act level.

The cartographic approach provides an interesting proposal to handle pragmatic aspects of the utterance. The question is, however, how many of these aspects should be distinguished. Besides speaker and hearer oriented particles, there are particles that have to do primarily with the structure of the ongoing discourse itself. For example, Dutch trouwens 'by the way' and eigenlijk 'actually' signal specific relations to the previous discourse, whereas for example integendeel 'on the contrary' raises expectations on what follows. Capturing these kinds of pragmatic contributions within the tree structure would require two additional functional projections as well as a decision on their hierarchical order. We don't say that this cannot be done, but for the moment, we think that a more low-level, surface structure oriented approach should precede cartographic theorizing.

Construction Grammar seems to be an attractive alternative, as it allows descriptions 'bottom-up'. This approach allows to assume a construction for each utterance final particle, and even for each of the three positions we distinguished for them in the right periphery. Correlations between types of meaning and positional behavior can be captured on a level that abstracts over the lower-level descriptions. The question is, then, how content 
constituents (extraposition and right dislocation) and one or more pragmatic particles are serialized in a specific utterance. The examples we have inspected so far do not raise the expectation that absolute rules are operating. There do seem to be 'natural preferences', however, such as: speaker oriented particles before hearer oriented ones, and backward looking particles before forward looking. The placement in relation to content constituents seems to be related, at least in part, to the diachronic source of the particle. For example hoewel 'although', which is derived from a subordinate conjunction, will be last in the serialization when used as a final pragmatic particle.

Recently, Imo (2008, 2010, 2011) has analyzed utterance final particles in German from an interactional-constructional perspective, cf. Auer (1991). In a corpus of 20 hours of spoken German, Imo (2011) found 86 expressions with a pragmatic function. The majority of them, 51 , looked like local and temporal deictic adverbs, such as hier 'here', da 'there', heute 'today' and jetzt 'now'. Imo argues that their function should be distinguished from occurrences of the same form in the middle field of the utterance. Utterance finally, he claims, they embed the utterance as a whole in the present speech situation. He thus assumes a separate constructional pattern for the utterance final use. Other expressions that occurred utterance finally and did not contribute to the propositional content were modal adverbs like natürlich 'naturally' and irgendwie 'somewhere', intensifiers like extrem 'extremely' and absolut 'absolutely', adjectives like wacker 'awake' and langsam 'slowly', and modal particles like halt 'as we both know' and einfach 'simply', as well as some others.

An interesting question brought up by Imo is in how far the utterance final occurrence of a word can be regarded as a performance phenomenon, for example as an online repair in an incremental production process. He does not reject such an analysis as adequate for certain concrete utterances, but on the whole, he sees enough recurrent patterns to assume that they are instantiations of a conventionalized construction. In his 2008 paper, he discusses utterance final halt more extensively and proposes that a constructional analysis should allow a certain syntagmatic flexibility. Besides the more frequent placement of halt in the middle field, placement at the end is allowed, which might be related to a not yet completed process of grammaticalization. We thus see that Imo's descriptive proposals depend on what seems adequate in relation to the corpus data: a separate construction for the utterance final particle, a construction which covers more than one positional option, and a 'repair' analysis. In this spirit, we looked at occurrences of utterance final particles in spoken Dutch. The main findings will be reported in the next section.

\section{An inventory of sentence final particles}

In this section, we discuss a number of examples of particles occurring at the right-hand side of the verbal complex. In traditional terminology, we will consecutively deal with interjections, modal particles, focus particles, adverbs, and conjunctions. Most of our examples are taken from the Spoken Dutch Corpus (CGN).

\subsection{Sentence final interjections}

The American linguist Bob Kirsner was the first to sow that little words like hoor and hè, joh and zeg, usually categorized as interjection, are quite happy at the end of utterances (see Kirsner 2000, Kirsner \& Deen 1990, Kirsner, van Heuven and van Bezooijen 1994, Kirsner and van Heuven 1996). The elements under discussion are of different pedigree: hoor (lit. 'hear') and zeg (lit. 'say') are of verbal origin, joh derives from a noun (< jongen 'boy', Den Boon et al. s.v.), and hè's etymology is unclear (that is to say, the scientific dictionary WNT (Volume 6,1912, 173-175) is silent on the subject). The four words occur after the verbal complex regularly:

(4) a. ja dan moet je ook zeker wel bijlezen soms hoor. 
Yes then must you too certain yet extra.read sometimes HOOR

'one certainly has to do some extra reading then sometimes, mind you!'

b. 'k weet helemaal niet waar 't dorpsplein is daar joh.

I know totally not where the village.square is there $\mathrm{JOH}$

'I really don't know where to find the village square there, you know'

c. en dan heb je een hele hoop te doen in huis hè.

And then have you a whole lot to do in home HE 'and then there is a lot to do in the house, you know'

d. maar da 's klote dat je net verkouden wordt dan zeg.

But that's bollocks that you just sick become then say

'but it's really annoying to catch a cold right at that moment, I think'

De Vriendt (1995: 157) takes a closer look at the syntagmatic possibilities of final interjections, focusing on zeg. He shows that extraposed constituents and vocatives can follow interjections:

(5) a. Hij zag er heel erg vermoeid uit zeg na de wedstrijd

He saw there very much tired out say after the game

'He really looked very tired after the game'

b. Je ziet er vreselijk down uit zeg, Jan

You look there terribly down out say, Jan

'Hey, you look terribly down, Jan'

Postverbal vocatives can be seen as an instance of right dislocation. We can thus, conclude, that final interjections can be followed by the two structural positions that are available for propositional information in the right periphery of a Dutch sentence.

\subsection{Sentence finale modal particles}

Words such as misschien 'perhaps', toevallig 'accidently' and soms 'sometimes' can be used to make questions more polite. If they are used this way, they are virtually indistinguishable from modal particles. It is therefore hardly surprising that they occur in the middle field, the typical locus for modal particles (Krivonosov 1977).

(6) a. heeft u soms één of andere stofzuiger in de aanbieding?

Have you sometimes one or other dust.sucker in the offer?

'do you perhaps have a vacuum cleaner for a special price?'

b. bent u misschien iets kwijt?

Are you perhaps something lost?

'do you miss something perhaps?'

c. weet je toevallig waar ie die bewaarde?

Know you accidently where he that kept?

'do you know by chance where he kept that?'

But we find them in sentence final position as well, with, according to our intuitions, the same contribution to the interpretation:

(7) a. heeft u vastgezeten in Oostenrijk toevallig?

Have you fast-sit in Austria accidently?

'have you by chance been stuck in Austria?'

b. heeft iemand het gezien of gehoord soms?

Has somebody it seen or heard sometimes?

'Did somebody see it perhaps?'

c. maar die kunnen toch geslecht worden misschien? 
But those can yet demolished become perhaps?

'But perhaps they can be demolished?'

Example (7a) shows that toevallig 'accidently' is in a position after the extraposed constituent in Oostenrijk. We would indeed prefer this order instead of (7a'), where the modal particle is in between the final verb cluster and the extraposed constituent:

$$
\begin{aligned}
& \text { ?heeft u vastgezeten toevallig in Oostenrijk? } \\
& \text { Have you fast-sit accidently in Austria? }
\end{aligned}
$$

The data in (6) and (7) can be seen as support for Imo's (2008) suggestion that modal particles are more flexible than is generally assumed. A position in the right periphery obviously does not preclude interpretation as a modal particle.

\subsection{Sentence final focus particles}

The corpus offers many examples of the well-known focus particles ook 'too, also', alleen 'only' and zelfs 'even' in positions after the verbal cluster:

(8) a. jij hebt dus ons ingeschreven voor voorlezen ook.

You have thus us in.scribed for for.reading also

'So you have enrolled us for reading aloud as well'

b. ja oké maar ja da's als je mentor bent ook.

Yes ok but yes that's if you mentor are also

'yes ok but yes that is if you are a mentor too'

c. en dan moet je tijgerbalsem kopen ook.

And then must you tiger.balm buy also

'and then you have to buy tiger balm as well'

d. dan kun je eigenlijk wel ontzettend veel gaan doen zelfs.

Then can you actually well extremely much go do even

'in that case you can even start doing a whole lot of things'

e. de meesten weten nog steeds niet dat ie bestaat zelfs.

The most know yet still not that he exists even

'Most people even still don't know that he exists'

f. d'r zit niet echt een verhaal in alleen. da's wel jammer.

There sits not really a story in only. That's well pity'

'the only thing is that there is not really a story in it. That's a pity'

g. moet je nog effe leren alleen.

Must you yet briefly learn only

'you only have to learn that yet'

Example (8a) shows that ook can occur in a position after "de laatste zinsplaats", as that is filled here with the prepositional phrase voor voorlezen 'for reading aloud'. Other

expressions which behave more or less like focus particles such as met name 'lit. by name; in particular' and maar liefst 'no(t) less than' occur in final positions as well:

(9) a. hij gaf een beetje aan hoe dat in Europa ligt met name.

He gave a bit on how that in Europe lies MET NAME

'he sort of explained the situation, in particular in Europe'

b. ze springen ver met name. en kangoeroes zijn heel sterk hè.

They jump far MET NAME. and kangaroos are very strong hè

'they jump far in particular. and kangaroos are very strong, you know'

c. honderd vijftig maar liefst.

Hundred fifty MAAR LIEFST

'no less than one hundred and fifty' 
Just as in the case of modal particles, placement of focus particles in the right periphery apparently does not cause interpretation problems (cf. also Foolen et al. 2009). We assume that intonation helps the hearer in deciding which constituent is meant as the focus the particle relates to.

Certain combinations seem to be (part of) of constructions all by themselves. A case in point is (en) nog ... ook, that consists of polyfunctional nog ('yet', among other things) and final ook 'too':

(10) a. dus ik moet waarachtig nog opschieten ook. So I must truly NOG hurry too 'so I really have to worry as well'

b. en volgens mij kan hij nog rijden ook. And according to me can he NOG drive too 'and as far as I know he can drive too'

c. en ze kan nog goed leren ook. And she can NOG good learn too 'and on top of that, she is also a good pupil'

d. en nog met vissmaak ook.

And NOG with fish.taste too 'and tasting of fish as well'

The meaning conveyed seems to be a combination of focus and mirativity (cf. Kim \& Jahnke (2011) for a comparable usage of English even). Utterances of this type typically do not occur at the beginning of a discourse, but rather conclude a story, and form the culmination of it. If ook's position is in the middle field rather than at the end of the utterance (en ze kan ook nog goed leren), the special meaning disappears and the 'simple' additive meaning (König 1991) is all that is left. We see this as an argument for development into a construction in its own right.

\subsection{Sentence final adverbs}

Various types of adverbs are found in the right periphery (Van der Wouden 2009). Here, we restrict ourselves to adverbial elements that either link the utterance to an earlier one. Dan 'then' occurs in sentence final position quite frequently in the corpus: ${ }^{1}$

In questions:

(11) a. heb jij wel een kattenbak? waar heb je die staan dan? Have you well a cats.bin? Where have you that stand then?

'You do have a dickey, don't you? But where do you keep it?'

b. wat ga je buiten doen dan?

wat go you outside do then?

'What are you going to do outside?'

In assertions:

(12) a. daar moet je ook niet over zeuren dan.

There must you also not over nag

'then don't nag about that'

b. maar goed uhm ja dus dat is geregeld dan.

\footnotetext{
${ }^{1}$ Haegeman (1991) and Capelle (1993) discuss cognates of dan in Dutch dialects. Final dan is considered to be a shibboleth of various city dialects from the Western part of the Netherlands (Holland) (Jansen (1981), Wortel (2002), Heestermans (2007),) (kejje nie hore dattik uit Roterdam komp dan? 'can't you here I'm from Rotterdam THEN'; Komie uit Leie dan? 'Are you from Leiden THEN?') but we are not aware of any grammatical analysis (cf. also Van der Wouden 2009, note 24).
} 
But good uh yes so that is settled then

'OK so that is settled'

In a few cases we found material between the verbal cluster and $d a n^{2}$

(13) a. welk bos heb jij gewandeld gister dan?

Which wood did you walk yesterday then

'[in] which wood did you go for a walk then yesterday?'

b. dus dat was toch niet zo handig geweest inderdaad dan.

Thus that was yet not so handy been indeed then

'so that wouldn't have been so useful after all'

Immers 'after all' and namelijk 'namely' occur occasionally in final position as well:

(14) a. maar ja je moet ook iedere keer op de grond zitten immers.

But yes you must also each time on the floor sit IMMERS

'I admit, each time you have to sit on the floor after all'

b. ik heb 't ook op mijn andere computer immers.

I have it also on my other computer after all

'I still have it on my other computer as well after all'

(15) a. het smaakt alsof het losse thee is namelijk.

It tasts as.if it loose tea is namely

'because it tastes like tea leaves'

b. ja maar ik weet niet of dat hierin staat namelijk.

Yes but I know not if that here.in stands namely

'yes but I don't know whether it's in here'

The same holds for dus 'thus, therefore', which also occurs in other positions. As we do not want to see it as a meaningless filler (contrary to the prestigious Van Dale dictionary's description as "betekenisloos", i.e. meaningless (Den Boon et al. 2005), we tend to ascribe it intersubjective value: a request for solidarity, or an appeal to a common ground.

(16) a. die avond moest 't gebeuren dus.

That night must it happen thus

'So that night it should happen'

b. ik werd om half negen wakker gebeld dus.

I was at half nine awake called thus

'so they woke me up with their phone call at eight thirty'

c. die heeft 't nog nooit zo druk gehad als nu dus.

That has it yet never so busy had as now thus

'so he has never been as busy as he is now'

d. ik heb er nooit moeite mee gehad hoor dus.

I have there never problem with had PRT thus

'so I never had any problems with it, mind you'

Example (16c) shows that dus can occur after the "laatste zinsplaats", in (15d) it follows the sentence final discourse particle hoor.

\subsection{Sentence final conjunctions}

\footnotetext{
${ }^{2}$ The particle combination dan ook is far from rare in final position, but that usually is a separate lexical item marking indefinite pronouns, e.g. geen gesprek over welk onderwerp dan ook no conversation about which subject DAN OOK 'no conversation about whatever subject' cf. Paardekooper (1978), Haspelmath (1997).
} 
McGloin \& Konishi (2010) observe that the Japanese coordinating particle shi 'and' can be used sentence finally. A comparable usage has been reported for but in several varieties of English (Mulder et al. 2009, Hancil 2010). Examples of final en 'and', maar 'but' and of 'or' are easily found in our corpus:

(17) a. en ik uh zit al die artikelen te lezen en...

And I uhh sit all those articles to read and

'and I am reading all those papers and...'

b. ja ze is gewoon zeiknat en...

Yes she is normally piss.wet and 'yeah, she is simply soaking wet and...'

c. ja daar heb ik alleen niet zo heel veel foto's van maar... yes there have I only not so very many photo's of but 'yes but the only thing is that I don't have too many pictures but...'

d. die staat hier nog niet op maar...

that stands here yet not up but

'it's not yet in there but...'

e. wat is dit voor foto is die niet afgedrukt of..

What is this for photo is that not printed or

'what kind of picture is this, didn't they print it or...'

f. ze hadden gewoon wel Europese muziek of...

they had normally well European music or

'they did have normal European music or...'

In general, however, one cannot end a Dutch sentence with a conjunct:

(18) a. ${ }^{*} \mathrm{Hij}$ is lief maar.

$\mathrm{He}$ is sweet but

b. *Hij verkoopt aardappelen en.

He sells potatoes and

c. ${ }^{*} Z e$ wordt president van de Nederlandse Bank of.

She becomes president of the Nederlandse Bank or

These sentences, or rather utterances, improve dramatically if we add a hesitation marker such as uh:
a'. Hij is lief maar uh
He is sweet but uh
b'. Hij verkoopt aardappelen en uh
He sells potatoes and uh
c'. Ze wordt president van de Nederlandse Bank of uh
She becomes president of the Nederlandse Bank or uh

Indeed the corpus contains a large number of utterances with a final conjunct followed by an explicitly transcribed hesitation:

(20) a. die kan ook zichzelf even voorstellen en uh...

That can ook himself briefly introduce and uh

'he can also simply introduce himself and uh'

b. maak je een plattegrondje en dan kan je d'r banken neerzetten en uh... make you a mapDIM and then can you there couches put and uh

'[then] you draw a little map and then you can place your couches and uh

c. 'k heb 'm natuurlijk niet zo lang gekend maar uh...

I have him naturally not so long known but

'Of course I sidn't know him that long but uh' 


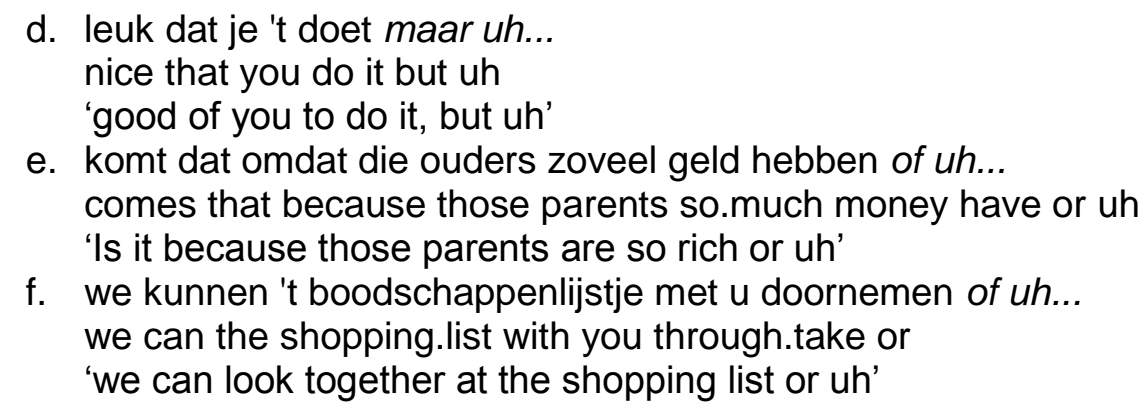

This raises the question whether combinations such as en uh and of uh should be seen as with a primarily discourse organizing function ("I as the current speaker indicate that I am willing to continue my turn, but that the addressee may take over as well"). Further research is needed to answer this. If the answer is affirmative, then one way of looking at these alleged lexical elements is as being the most general cases of "general extenders" in the sense of Overstreet (1999) (cf. also Van der Wouden 2011).

\section{Utterance final particles in other languages}

Within the Germanic language family, Norwegian seems to be the language which uses utterance final particles most extensively, cf. Andvik (1992), Askedal (1989) and Fretheim $(1989,1991,2010)$. Askedal (1989) takes a typological perspective in comparing Norwegian to German, with its many modal particles in the middle field. Starting from V as nucleus, German serializes to the left, with $\mathrm{O}$ before $\mathrm{V}$ and modal particles ending up to the left of $\mathrm{O}$, in the middle field. Norwegian, on the other hand, serializes to the right, with $\mathrm{O}$ to the right of the nucleus $\mathrm{V}$ and particles ending after $\mathrm{O}$ on the far right. Dutch fits this picture, with its preference for modal particles in the middle field, but English, being more strongly SVO than Norwegian, should show a strong preference for utterance final particles, which it does not. There is, thus, reason for some doubt with regard to the typological explanation. This doubt becomes only stronger when we look at other languages.

Outside of Europe, research on utterance final particles focuses on East Asian languages, cf. van Minde (1997: 250-259) on Ambong Malay, Person (2000) on Bisu (Thailand), and Deepadung \& Ratanakul (1997) on Mal (Thailand and Laos). For Japanese Lee (2007), Haugh (2008), McGloin \& Konishi (2010), Saigo (2011) and Hayano (2013). For (different varieties of) Chinese, see Li (2006), Lin (2010), Sybesma \& Boya (2007), Sybesma (2010), Strauss \& Xiang (2009), Lee \& Pan (2010), Yap, Wang and Lam (2010).

Typological differences seem to play a minor role here. Japanese is SOV and Chinese SVO, but the languages both make abundant use of final particles. It thus seems that more descriptive research on language specific preferences regarding the positioning of pragmatic particles is necessary, before typological or other explanations have a chance to succeed. Looking at Dutch again, it is clear that categorical statements cannot be made: pragmatic particles can be found in all candidate positions. With candidate positions, we mean 'natural' positions like the beginning and the end, in the middle field between theme and rheme (cf. Krivonosov 1977), and in the Wackernagel position (after the first word or constituent). Finer distinctions are possible, as we have seen for the right periphery already. In the next section, we will show that Dutch pragmatic particles can indeed be found 'all over the place'.

\section{Dutch particles in non-final positions}

Dutch pragmatic particles can not only be found in the middle field (between the verbal bracket of V2 and Vfinal) and in the right periphery, but also in the left periphery. This is not the place to discuss the different positions within the left periphery that have been proposed 
in the literature. We simply assume that there are at least three candidate positions. From left to right we can distinguish a position that precedes the sentence proper, like left dislocation does, then there is the so-called 'first sentence position', where subject and topicalized constituents are located, and thirdly there is a special position called 'Wackernagel position', between the first sentence position and the V2 position for the finite verb.

(21) Left periphery:

nou ik zie dat plan met de vakantie ook echt niet zitten hoor.

PRT I see that plan with the holiday also really not sit PART

'Well, I really don't like that holiday plan either, you know'

(22) First sentence position:

nou heb ik 't weer gedaan.

PRT have I it again done

'they're blaming me again'

(23) Wackernagel position:

In den beginne schiep God de hemel en de aarde. De aarde nu was woest en ledig, en duisternis lag op de vloed, en de Geest Gods zweefde over de wateren.

(Genesis 1: 1-2, Willibrordvertaling)

In the beginning God created the heaven and the earth. And the earth was without form, and void, and darkness was upon the face of the deep. And the Spirit of God moved upon the face of the waters.

To give an example of a particle in the middle field, we can use nou 'now' (cf. (22) where it is in first sentence position):

(24) Middle field

ik ken nou echt niemand die werkeloos is

I know now really nobody that jobless is

'I really don't know anybody without a job'

Some particles are restricted in their distribution. The interjection hoor only occurs in the right periphery, whereas the modal particles have a strong preference for the middle field. But there are also particles that are rather flexible positionally, for example kortom 'in brief, summarizing', cf. (25):
a. kortom 't is gewoon een hele belabberde situatie.
Summarizing it is simply a very miserable situation
'in brief, the situation is miserable'
b. je kijkt er kortom niet met veel vreugde op terug. You look there summarizing not with much joy on back
'to summarize, looking back doesn't make you happy'

c. [ik] pleit ervoor dat ze wel mogen gehoord worden de pleegouders kortom.

I plead there-for that they well may heard be the foster-parents in brief

'In short, l'd like to argue that the foster parents should be listened to'

In the last examle, the phrase de pleegouders is a right dislocated constituent. Addition of kortom after this constituent sounds like a repair, but it is a real example. A similar paradigm of examples can be given for trouwens 'incidentally, by the way', cf. (26):

(26) a. trouwens jij moest mij nog iets vertellen over die husky of niet?

By the way you must me yet something tell about that husky or not?

'by the way, you wanted to tell me something about that husky, didn't you?'

b. dat had ik trouwens in 't vorige gesprek ook al gezegd volgens mij. 
That had I incidentally in the last conversation too already said according-to me

'I think I mentioned that in our last talk alredy'

c. ja we hebben ook wel heel veel ruzie gemaakt hoor trouwens.

Yes we have also well whole much quarrel made PRT incidentally

'by the way, we also quarreled a lot, don't forget that'

Note that in (26c) there are two particles in the right periphery, hoor and trouwens. Reversal of the order of these two particles would be ok too, according to our intuitions. We complete our inventory of flexible particles with bovendien 'moreover, on top of that':

(27) a. bovendien was ik het enige meisje en de jongste in het gezin.

Moreover was I the only girl and the youngest in the family

'Moreover, I was the only girl and the youngest in the family'

b. marihuana is bovendien niet of nauwelijks verslavend.

Marihuana is moreover not or hardly addicting

'moreover, marihuana is hardly addictive'

c. daar ben ik helemaal niet voor gekleed bovendien.

There am I totally not for dressed moreover

'moreover, I am not at all dressed for the occasion'

If a particle can be used in different positions, then the questions arises whether the different positions imply differences in meaning. A cartographic approach (Cinque 1999, Poletto

2009) predicts differences in meaning, unless it can be shown that different positions are the result of movement. But for the examples we just gave for kortom, trouwens, and bovendien we find it hard to find real differences in meaning or function. Another example would be toch 'however', as in (28):
a. Dat is toch vreselijk!
That is PRT terrible
'that is terrible, isn't it?'
b. Dat is vreselijk toch?
That is terrible PRT
'that is terrible, isn't it?'

In (28a) the focus is a little bit more on the speaker's expressivity, whereas in the final position toch functions somewhat more as a hearer oriented prompt for a reaction. But intonation can 'neutralize' the difference. In contrast to these rather subtle examples, we see a clear difference in function with regards to zeg 'say'. When used in the left periphery, it's function is attention seeking, in the right periphery it strengthens the utterance.
a. Zeg luister eens
Say listen PRT
'Hey, listen to me'
b. Luister eens zeg
Listen PRT say
'Now you really have to listen to me'

Apparently, absolute claims about the relation between position and function of pragmatic particles cannot be made.

\section{Doubling}


A phenomenon that we we did not expect to find beforehand was the occurrence of one and the same particle twice, one time at the beginning or in the forefield and one time at the end. The examples in (30) contain two occurences of dan 'then'.

(30) a. dan hebben die vissen wel veel te veel gegeten dan. then had those fishes PRT much too much eaten then 'those fishes had eaten way too much then'

b. nou hij heeft mijn nek dan ook gekraakt dan. now he has my neck then too cracked then 'well he thus cracked my neck then'

c. dan heb je slechte bloedvaten dan. then have you bad vains then 'then you have bad vains then'

d. ik denk ja laat ik dan maar die kleine halen dan. I think yes let me then just that little get then 'I think well let me then pick up the little one then

Dan is a particle that occurs twice relatively often. Interestingly enough, Norwegian utterances also easily contain two occurrences of dan's cognate da, cf. Fretheim (1991:184):

(31) De sov da hjemme, da vel?

They slept then at home, then well?

'They surely did sleep at home then, didn't they?

Askedal (1989:695) already gave examples of da-doubling:

(32) Det var da fælt så lenge han ble da

That well da stays long time da

'That will stay for a a long time, won't it?

An explanation for this phenomenon could be that the Dutch dan and Norwegian da do indeed involve both a backward looking function and a forward one. On the one hand, the speaker indicates that his utterance was motivated by preceding discourse, on the other hand he indicates that he would appreciate a ratification or a comment from the hearer.

We also observed doubling of toch 'nevertheless, isn't it':

(33) ja dat zijn toch dingen die heel makkelijk te veranderen zijn op zich toch. yes those are toch things that very easily to change are in itself toch 'yes those are things that can be changed easily in itself, isn't it'

As we commented in relation to (28), toch in the middle field has a ring of speaker expressivity, whereas it is more hearer directed at the end. An utterance like Dat is toch verschrikkelijk toch? 'That is terrible, isn't it' sounds natural.

The third particle that often occurred twice in our data is ook 'also, too'.

(34) a. kun je ook nog nalezen ook.

can you also still check too

'You can check that too'

b. och ja da's ook waar ook.

ah yes that is also true too

'ah yes that is true all right'

c. dan zijn we er op een gegeven moment ook van af ook. then are we there at a given moment also from away too.

'then we have got rid of them at a certain moment too' 
In (34a), the utterance contains nog 'still', which together with the final ook constitutes a construction (see discussion on example 10). The first ook does not add much to the meaning of the utterance, at most a strengthening of the expressive value of the construction. A similar effect occurs when nog is added to the second part of the construction, the final ook, cf. (35):

$$
\begin{aligned}
& \text { het regent nog behoorlijk ook nog. } \\
& \text { It rains still quite a bit too still } \\
& \text { 'Moreover, it still rains rains quite a bit' }
\end{aligned}
$$

\section{Grammaticalization of final particles}

Pragmatic particles typically result diachronically from grammaticalization processes. Content words, but also function words, can develop an interactional and discourse potential and this functional shift often implies preferences for positions which are 'natural' for such particles, like the right periphery. Research in this field is still suffering from terminological uncertainties like when to speak of grammaticalization, pragmaticalization, constructionalization, or subjectification, cf. Degand \& Simon-Vandenbergen (2011), but there is no doubt that an approach along these lines is relevant for pragmatic particles.

For Dutch, not much research on the grammaticalization of final particles has been done but Evers-Vermeul et al. (2011) provide a good methodological example of how such research should look like. For English, more research is available, see Barth \& CouperKuhlen (2002) about though, Lewis (2011) about rather. Sentence-final but has been studied in Beeching (2007: 91-95), Zwicky (2008), Mulder, Thompson \& Williams (2009), and Hancil (2010).

The processes that led to final though and but seem relevant for Dutch hoewel 'though' and also for Taiwanese Mandarin la, cf. Lin (2010). According to Lin, la is normally followed by an 'elaboration', but if this is left out, then la keeps the implication "this is what I want to say and you should know" (Lin 2010:111). Barth-Weingarten and Couper-Kuhlen (2002:348) assume a similar process for though as used in it's their right to be heard though: "Final though here concedes a prior point but it does not make this point explicit. It is loosely anaphoric to the $X$ of prior discourse. Often it seems to be paraphrasable as 'though what you just said is true."

Probably, for other final particles other processes are responsible. For example, if a particle is realized utterance finally as a repair regularly, then this realization can become more and more acceptable, assuming, in the end, a function that it did not have in its initial position earlier in the sentence.

\section{Functions of final particles}

In spoken language, an utterance is often not finished when the propositional content has been formulated. Instead we see a pragmatic rounding off with pragmatic particles. Why? Several functions seem to be served by final particles. In the Dutch data, we perceived the following functions.

1. The final particle is part of a two particle construction, the first part of which is in the middle field. In Dutch this is the case with the nog ... ook construction, which adds an expressive, mirative, function to the utterance.

2. The final particle indicates the discourse function of the utterance, for example that it is meant as a warning or reassurance (hoor 'hear'), as a concluding summary (kortom 'in summary'), or as a tentative utterance to which the reaction of the hearer is prompted (hè, nietwaar 'isn't it'). 
3. After formulating a thought, the speaker inspects what he has said and considers it as too strong. Weakening can take place by different types of final particles, like the general extender of zo 'or so', hoewel 'although', and Flemish X toch ' $X$ at least', where $X$ is an expression that replaces a stronger expression in the utterance and toch indicates this weakening function. Weakening is often part of a politeness strategy.

4. Final conjunctions, followed by a hesitation signal can be used to 'fade out': The speaker indicates that the turn is open for negotiation. The speaker offers the hearer the possibility to take the turn, at the same time showing willingness to continue if the hearer is not prepared to take over. Again, politeness seems to be the main trigger behind this behavior.

5. Some final particles are 'repairs', forgotten particles, like in Ik ben toen naar huis gegaan maar 'I went home then', where the maar is normally realized directly after toen in the middle field. Conventionalisation of repairs can lead to final particles with their own function.

The functions we just summed up should be compared with functions of final particles in other languages. The comparative study hopefully leads to a list of functions that can be taken as a starting point for studying final particles cross-linguistically.

\section{Conclusion}

We realize that we have made just a first exploration of final particles in Dutch. First, we do not claim that the inventory we presented is exhaustive. Second, we have shown that there are several positions in the right periphery and that specific particles prefer specific positions, but for a full picture of the syntagmatic possibilities and constraints, it would be necessary to analyze more examples and to check them against the intuitions of native speakers. We have discovered some special phenomena. Final ook 'too' can be part of a construction which has nog as the other obligatory element in the middle field. And we discovered the phenomenon of particle doubling. Finally, we proposed a list of functions that final particles typically fulfill. But this is only the start, a fine grained analysis of the function(s) each final particle can fulfill is work for future researchers, who, we hope, find some inspiration in our first exploration of particles in the Dutch right periphery.

\section{Bibliography}

Andvik, Erik E. 1992. A pragmatic analysis of Norwegian modal particles. Dallas, TX: International Academic Bookstore.

Askedal, John Ole. 1989. Sprachtypologische Aspekte norwegischer Partikelstrukturen. In H. Weydt (ed.), Sprechen mit Partikeln, 691-702. Berlin: Mouton de Gruyter.

Auer, Peter. 1991. Vom Ende deutscher Sätze. Zeitschrift für germanistische Linguistik 19. 139-157.

Averintseva-Klisch, Maria. 2009. Rechte Satzperipherie im Diskurs. Die NPRechtsversetzung im Deutschen. Tübingen: Stauffenburg Verlag.

Bart-Weingarten, Dagmar \& Elizabeth Couper-Kuhlen. 2002. On the development of final though. A case of grammaticalization. In Ilse Wischer \& Gabriele Diewald (eds.), New Reflections on Grammaticalization, 345-361. Amsterdam: Benjamins.

Beeching, Kate. 2007. A politeness-theoretic approach to pragmatic-semantic change. Journal of Historical Pragmatics 8(1). 69-108.

Benincà, Paola \& Nicola Munaro (eds.). 2010. Mapping the left periphery. The cartography of syntactic structures, Vol. 5. Oxford: Oxford University Press.

Boon, Ton den, Dirk Geeraerts \& Nicoline van der Sijs. 2005. Van Dale Groot woordenboek der Nederlandse taal, 14th ed. Utrecht/Antwerpen: Van Dale Lexicografie. 
Breul, Carsten. 2004. Focus structure in generative grammar. An integrated syntactic, semantic and intonational approach. Amsterdam: Benjamins.

Capelle, Bert. 1993. Het gebruik van het Brugse dialoogpartikel dè (/dæ/). neerlandistiek.nl 03.01 .

Cinque, G. 1999. Adverbs and functional heads: A cross-linguistic perspective. New York \& Oxford: Oxford University Press.

Deepadung, Sujaritlak \& Suriya Ratanakul. 1997. Final particles in conversational Mal (Thin). Mon-Khmer Studies 27, 81-89.

Degand, Liesbeth \& Anne-Marie Simon-Vandenbergen (2011). Introduction: Grammaticalization and (inter)subjectification of discourse markers. Linguistics 49(2). 287-294.

De Vriendt, Sera. 1995. Kom, kijk, zeg als interjectie. In Sera De Vriendt, Van geen kleintje vervaard. Essays over Nederlandse taalwetenschap, 151-159. Brussel: VUB Press.

Evers-Vermeul, Jacqueline, Liesbeth Degand, Benjamin Fagard \& Liesbeth Mortier. 2011. Historical and comparative perspectives on subjectification: A corpus-based analysis of Dutch and French causal connectives. Linguistics 49(2). 445-478.

Foolen, Ad. 1993. De Betekenis van Partikels. Een dokumentatie van de stand van het onderzoek met bijzondere aandacht voor maar. Dissertation Nijmegen.

Foolen, Ad, Richard van Gerrevink, Lotte Hogeweg \& Peia Prawiro-Atmodjo. 2009. The placement of focus particles in Dutch. In B. Botma \& J. van Kampen (eds.), Linguistics in the Netherlands 2009, 51-63. Amsterdam: Benjamins.

Fretheim, Thorstein. 1989. The two faces of the Norwegian inference particle da. In H. Weydt (ed.), Sprechen mit Partikeln, 403-415. Berlin: Walter de Gruyter.

Fretheim, Thorstein. 1991. Formal and functional differences between S-internal and Sexternal modal particles in Norwegian. Multilingua 10(1/2). 175-200.

Fretheim, Thorstein. 2010. The metarepresentational use of main clause phenomena in embedded clauses. Linguistics 48(2). 301-324.

Haeseryn, Walter, Kirsten Romijn, Guido Geerts, Jaap de Rooij \& Maarten C. van den Toorn. 1997. Algemene Nederlandse Spraakkunst. 2nd ed. Groningen/Deurne: Martinus Nijhoff/Wolters Plantijn.

Haegeman, Liliane. 1993. The interpretation of the particle da in West Flemish. Lingua 90. 111-128.

Haegeman, Liliane. 1991/2008. Parenthetical adverbials: The radical orphanage approach. In Benjamin Shaer et al. (eds.), Dislocated elements in discourse. Syntactic, semantic, and pragmatic perspectives, 580-611. London: Routledge.

Haegeman, Liliane \& Virginia Hill. 2010. The syntactization of discourse. Paper presented at ONLI Belfast December 2010.

Hancil, Sylvie. 2010. Grammaticalization of sentence-final but: from discourse connective to discourse marker. Paper International conference on final particles, Rouen, May 2010.

Haugh, Michael. 2008. Utterance-final conjunctive particles and implicatures in Japanese conversation. Pragmatics 18(3). 425-451.

Hayano, Kaoru. 2013. Territories of knowledge I Japanese conversation. (MPI Series in Psycholinguistics 76). PhD Nijmegen.

Heestermans, Hans. 2007. Het Leids woordenboek. Leiden: Selexyz Kooyker.

Imo, Wolfgang. 2008. Individuelle Konstrukte oder Vorboten einer neuen Konstruktion? Stellungsvarianten der Modalpartikel halt im Vor- und Nachfeld. In Anatol Stefanowitsch \& Kerstin Fischer (eds.), Konstruktionsgrammatik II. Von der Konstruktion zur Grammatik, 135-155. Tübingen: Stauffenburg Verlag.

Imo, Wolfgang. 2010. Das Adverb jetzt zwischen Zeit- und Gesprächsdeixis. Zeitschrift für germanistische Linguistik 38. 25-58.

Imo, Wolfgang. 2011. Ad hoc-Produktion oder Konstruktion? - Verfestigungstendenzen bei Inkrement-Strukturen im gesprochenen Deutsch. In A. Lasch \& A. Ziem (eds.), Konstruktionsgrammatik III. Aktuelle Fragen und Lösungsansätze, 239-254. Tübingen: Stauffenburg Verlag. 
Jansen, Frank. 1981. Syntaktische konstrukties in gesproken taal. PhD Leiden.

Kim, Min-Joo \& Nathan Jahnke. 2011. The meaning of utterance-final Even. Journal of English Linguistics 39. 36-64.

Kirsner, Robert S. 2000. Empirical pragmatics: Downtoning and predictability in a Dutch final particle. In T.F. Shannon \& J.P. Snapper (eds.), The Berkeley Conference on Dutch Linguistics 1997 ( Publications of the American Association for Netherlandic Studies 12), 45-62. Lanham, MD: University Press of America.

Kirsner, Robert S. \& Jeanine Deen. 1990. Het mes snijdt aan twee kanten. On the semantics and pragmatics of the Dutch sentence-final particle hoor. In M. Bruijn Lucy (ed.), The Low Countries: Multidisciplinary Studies, 1-11. Lanham, MD: University Press of America.

Kirsner, Robert S., Vincent J. van Heuven \& Renée van Bezooijen. 1994. Interaction of particle and prosody in the interpretation of factual Dutch sentences. In R. BokBennema \& C. Cremers (eds.), Linguistics in the Netherlands 1994, 107-118. Amsterdam: Benjamins.

Kirsner Robert S. \& Vincent J. van Heuven. 1996. Boundary tones and the semantics of the Dutch final particles hè, hoor, zeg, and joh. In C. Cremers \& M. den Dikken (eds.), Linguistics in the Netherlands 1996, 133-146. Amsterdam: John Benjamins.

König, Ekkehard. 1991. The meaning of focus particles. London: Routledge.

Koster, Jan. 1975. Dutch as an SOV language. Linguistic Analysis 1. 111-136.

Krivosonov, Aleksej T. 1977. Deutsche Modalpartikeln im System der unflektierten Worklassen. In H. Weydt (ed.), Aspekte der Modalpartikeln, 176-216. Tübingen: Niemeyer.

Lee, Duck-Young. 2007. Involvement and the Japanese interactive particles ne and and yo. Journal of Pragmatics 39. 363-388.

Lee, Peppina Po-Lun \& Hai-Hua Pan. 2010. The landscape of additive particles - with special reference to the Cantonese sentence-final particle tim. Lingua 120. 17771804.

Lewis, Diana. 2011. A discourse-constructional approach to the emergence of discourse markers in English. Linguistics 49(2). 415-443.

$\mathrm{Li}$, Boya. 2006. Chinese final particles and the syntax of the periphery. Dissertation Leiden.

Lin, Chin-hui. 2010. The utterance-final particle la in Taiwan Mandarin. In Jacqueline van Kampen \& Rick Nouwen (eds.), Linguistics in the Netherlands 2010,101-114. Amsterdam: Benjamins.

McGloin, Naomi. H. \& Yumiko Konishi. 2010. From connective particle to sentence-final particle: a usage-based analysis of shi 'and' in Japanese. Language Sciences 32(5). 507-588.

Mulder, J.G., S. Thompson and C. Perry Williams. 2009. Final but in Australian English conversation. In P. Peters et al. (eds.), Comparative studies in Australian and New Zealand English: Grammar and beyond, 339-359. Amsterdam: Benjamins.

Overstreet, Maryann. 1999. Whales, candlelight, and stuff like that: general extenders in English discourse. New York: Oxford University Press.

Paardekooper, P.C. 1968. Beknopte ABN-syntaksis. Den Bosch: Malmberg.

Paardekooper, P.C. 1978. Wie dan ook enz., vooral als patroondeel. De Nieuwe Taalgids 71. 569-581.

Person, Kirk Roger. 2000. Sentence final particles in Bisu narrative. PhD, University of Texas at Arlington.

Poletto Cecilia. 2009. Two cases of cycle reduction: sentential particles in Old Italian. In E. van Gelderen (ed.), Cyclical change, vol. 1, 185-208. Amsterdam: Benjamins.

Ross, John Robert. 1970. On declarative sentences. In R.A. Jacobs \& P.S. Rosenbaum (eds.), Readings in English transformational grammar, 222-272. New York: Oxford University Press.

Saigo, Hideki. 2011. The Japanese sentence-final particles in talk-in-interaction. Amsterdam: Benjamins.

Schelfhout, Carla. 2006. Intercalations in Dutch. PhD Nijmegen. 
Schermer, Ina. 2007. Wat doet dat woord daar, zeg? Over het tussenwerpsel zeg. Voortgang. Jaarboek voor de Neerlandistiek 25. 373-385.

Schneider-Wiejowksi, Karina. 2010. Komplexe syntaktische Konstruktionen nach der rechten Satzklammer: Eine Korpusstudie. Muttersprache 2010(1). 57-69.

Strauss, Susan \& Xuehua Xiang. 2009. Discourse particles: Where cognition and interaction intersect. The case of final particle ey in Shishan dialect (Hainan Island, P.R. China). Journal of Pragmatics 41. 1287-1312.

Sybesma, Rint. 2010. Het loze van tijdenloosheid. Inaugural lecture Leiden.

Sybesma, Rint \& Boya Li. 2007. The dissection and structural mapping of Cantonese sentence final particles. Lingua 117. 1739-1783.

Uijlings, Berthe. 1956. Praat op heterdaad. Assen: Van Gorcum.

van Minde, Don. 1997. Malayu Ambong. Phonology, Morphology, Syntax. Leiden: CNWS.

Veld, Joop 1993. Postverbal constituents in Dutch and Turkish (Amsterdam Studies in Generative Grammar 6). PhD Amsterdam

Vries, Matthias de \& Lammert te Winkel et al. (eds.). 1864-1998. Woordenboek der Nederlandsche Taal. 's-Gravenhage [etc.]: Martinus Nijhoff [etc.].

Wortel, Dick. 2002. Leids. Den Haag: Sdu Uitgevers.

Wouden, Ton van der. 2000. Focus on appendices in Dutch. In Helen de Hoop \& Ton van der Wouden (eds.), Linguistics in the Netherlands 2000, 233-245. Amsterdam: Benjamins.

Wouden, Ton van der. 2006. Partikels: woordjes die het Nederlands markeren. In: Nicoline van der Sijs, Jan Stroop, \& Fred Weerman (eds.), Wat iedereen van het NEDERLANDS moet weten en waarom, 119-129. Amsterdam: Bert Bakker.

Wouden, Ton van der. 2009. Ik zou weleens willen weten waar dat woord staat trouwens. Aantekeningen over zinsfinale bijwoorden. In Ronny Boogaart, Josien Lalleman, Marijke Mooijaart \& Marijke van der Wal (eds.), Woorden wisselen. Voor Ariane van Santen bij haar afscheid van de Leidse universiteit, 143-156. Leiden: SNL.

Wouden, Ton van der. 2011. General extenders en zo. Paper, Tindag, February 5, 2011.

Yap, Foong Ha, Jiao Wang and Charlies Tsz-kwan Lam. 2010. Clausal integration and the emergence of mitigative and adhortative sentence-final particles in Chinese. Taiwan Journal of Linguistics 8(2). 63-86.

Zwicky, Arnold. 2008. Final conjunctions. http://languagelog.ldc.upenn.edu/nll/?p=119. (accessed 10 April 2011). 